\title{
Post Waterflood C02 Miscible Flood in Light Oil Fluvial- Dominated Deltaic Reservoirs
}

\author{
Quarterly Report \\ July 1 - September 30, 1997 \\ By: \\ John Augustine
}

Work Performed Under Contract No.: DE-FC22-93BC14960

\author{
For \\ U.S. Department of Energy \\ Office of Fossil Energy \\ Federal Energy Technology Center \\ P.O. Box 880 \\ Morgantown, West Virginia 26507-0880
}

By

Texaco Exploration \& Production Inc.

P. O. Box 1650

Tulsa, Oklahoma 74105 


\section{Disclaimer}

This report was prepared as an account of work sponsored by an agency of the United States Government. Neither the United States Government nor any agency thereof, nor any of their employees, makes any warranty, express or implied, or assumes any legal liability or responsibility for the accuracy, completeness, or usefulness of any information, apparatus, product, or process disclosed, or represents that its use would not infringe privately owned rights. Reference herein to any specific commercial product, process, or service by trade

name, trademark, manufacturer, or otherwise does not necessarily constitute or imply its endorsement, recommendation, or favoring by the United States Government or any agency thereof. The views and opinions of authors expressed herein do not necessarily state or reflect those of the United States Government or any agency thereof. 
4th Quarter, Fiscal Year 1997

Post Waterflood $\mathrm{CO}_{2}$ Miscible Flood in Light Oil Fhated Ddebtaic Reservoirs.

DE - FC22 - 93BC14960--20

Texaco Exploration \& Production Inc.

January 13, 1998

Awhunde Dat4993

pletidmedeate: 1997

Gutvdmard for Current Fiscal Year

$\$ 523,000.00$

Pỳojectiniphanger (Texaco

COR: Chandra Na(IDYul

Contract specialist (DOE) ： John Augustine

\section{Dúphrdbgy, 1997ough Septe}

US. DOE patent Clearance is not required prior to the publication of this document 


\section{TABLE OF CONTENT}

Executive Summary $\quad$ Pge

Fourth Quarter, 1997 Objectives $\quad 1$

Discussions of Results - Field Operations $\quad 1$

Discussion of Results - Technology Transfer 1

First Quarter, 1998 Objectives $\quad 1$

Figures: $\quad$ 1-Allocated Reservoir Production 2

Post Waterflood $\mathrm{CO}_{2}$ Miscible Flood in Light Oil Fluvial-Dominated Deltaic Reservoirs

“DE - FC22 - 93BC14960" 


\section{Technical Progress Report}

Fourth Quarter, 1997

\section{Executive Summary.}

Only one well remains on production in the Port Neches $\mathrm{CO}_{2}$ project; Kuhn \#14. Production from this project is approaching economic limit and the project is nearing termination at this point. The workover to return Kuhn \#38 to production failed and the well is currently shut in. All produced $\mathrm{CO}_{2}$ is currently being reinjected in the reservoir. The $\mathrm{CO}_{2}$ recycled volume is 2 MMCFD.

\section{Fourth* Quarter 1997, Objectives.}

* Monitor reservoir performance, and evaluate the project economics .

No change in project operation since the second quarter report. The project is at a negative cash flow because of the workover failure at Kuhn \#38.

\section{Discussion of Results - Field Operations.}

The following is a list of the most recent well test taken during the month of September 1997, for the producing and injection wells:

Producer: $\quad$ Kuhn \#14, 33 BOPD, $96 \%$ BS\&W, $\quad 420$ PSI, $\quad 36$ CK.

Injection: No produced gas is being reinjected during September in preparation of project termination.

The Financial Status Report, Management Summary, Milestone Schedule and Federal Transaction Report are included in this report.

Discussion of Results - Technology Transfer.

No technology transfer activities is taking place during this period.

First Quarter 1998, Objectives.

* Monitor reservoir performance, and begin project termination. 